Revista Eletrônica Geografar, Curitiba, v. 2, Resumos do VI Seminário Interno de Pós-Graduação em Geografia, p. 50-50. Junho/2007

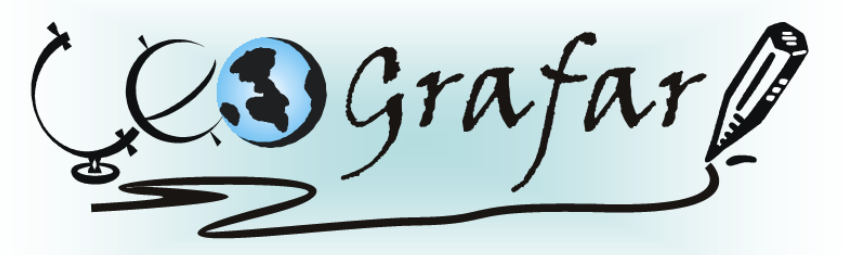

Revista Eletrônica do Programa de Pós-Graduação em Geografia - UFPR

\title{
SISTEMAS PEDOLÓGICOS NA SERRA DO MAR: SUBSÍDIOS PARA O CONHECIMENTO DA GÊNESE E DINÂMICA DOS MOVIMENTOS DE MASSA NAS BACIAS QUE DRENAM PARA A BAIA DE ANTONINA-PR
}

\author{
MARCIEL LOHMANN ${ }^{1}$
}

A Serra do Mar corresponde a um conjunto de escarpas festonadas com cerca de $1.000 \mathrm{~km}$ de extensão, estendendo-se do Rio de Janeiro ao norte de Santa Catarina. É constituída por um conjunto de blocos altos e baixos em maciços diversos os quais recebem dominações locais. Segundo Cordani e Girardi (1967), a Serra do Mar é uma serra marginal de borda de planalto, com um desnível acentuadamente maior para o lado do oceano do que para o lado continental, mas possuindo taludes e vertentes abruptas nos dois flancos. O relevo no domínio dessa unidade é bastante acidentado, com vales profundos, estreitos e vertentes rochosas muito íngremes. Reportando-se a área especificamente, ou seja, as bacias que drenam para a Baia de Antonina, a mesma é caracterizada por uma geomorfologia atípica no que diz respeito ao restante do estado, já que se tem um desnível de aproximadamente 1000 metros desde o início da Serra do Mar até o grande compartimento geomorfológico conhecido como planície costeira. Diferenças de litologia, solos, vegetação e uso e ocupação lhes dão uma característica singular e de múltiplos interesses. Associada a estas singulares características tem-se enormes problemas ligados principalmente às altas declividades associadas a solos muito rasos, como, por exemplo, movimentos de massa, queda de blocos e desmoronamentos. Diante do contexto apresentado, o presente estudo tem por principal objetivo aprofundar o conhecimento da cobertura pedológica das bacias hidrográficas que drenam para a Baia de Antonina (litoral do Paraná) através do mapeamento dos sistemas pedológicos em diversas escalas da paisagem, utilizando a abordagem morfopedológica (Castro e Salomão, 2000) como base, com vistas a trazer contribuições para o melhor entendimento da morfodinâmica da região.

Palavras-chave: Morofopedologia, Serra do Mar, Sistemas Pedológicos

${ }^{1}$ Doutorando em Geografia - UFPR - email: marciel_lohmann@yahoo.com.br Orientador: LEONARDO JOSÉ CORDEIRO SANTTOS 